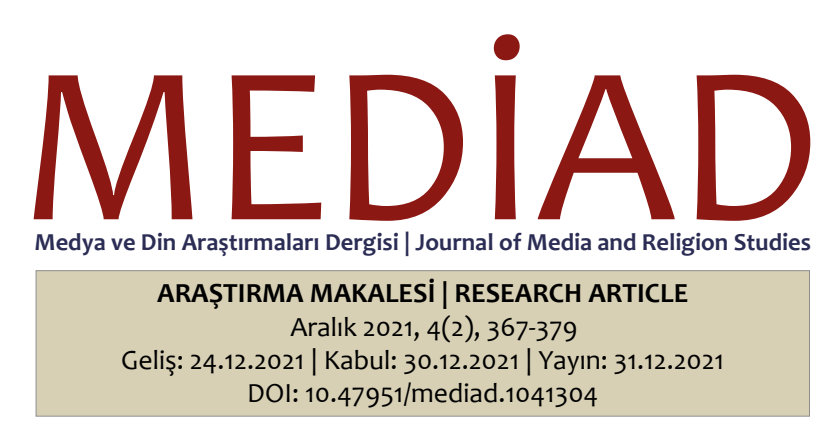

\title{
“Hakikat” Kavramının Dönüșümü: Bir Tarihsel Sosyoloji Denemesi
}

\author{
Fatmanur ALTUN*
}

\begin{abstract}
Öz
“Hakikat” entelektüel ağlarda ve gündelik dilde en sık başvurulan kavramlardan biridir. Bu durumun ortaya çıkmasında, sıradan insanlardan toplum liderlerine kadar hemen hemen herkesin, kendilerini ve pozisyonlarını, bir biçimde hakikat ile ilişkili olarak açıklama istekleri etkilidir. Neredeyse içgüdüsel olan bu yönelim hakikatin tarih boyunca da en fazla atıf alan kavramlardan biri olmasına neden olmuş, hakikatin nasıl elde edileceğine, hakikatin kaynağının ne olduğuna ve hakikati elinde bulunduran merciinin keyfiyetine ilişkin anlaşmazlıklar ve uzlaşılar tarih boyunca ortaya çıkmıştır. İnsanoğlunun hakikate sahip olmak yahut hiç değilse onun yanında saf tutmak şeklindeki bu içgüdüsü, günümüzde de varlığını korumaktadır. Hakikat üzerine sayısız açıklama ve tartışmalar devam etmekte ve bu tartışmaların siyasal, toplumsal sonuçları ortaya çıkmaktadır. Özellikle 1970'li yıllardan itibaren yoğunluğu artan bu tartışmalar, günümüzde adeta "hakikatin sonu" çağrıları eşliğinde yürütülmektedir. Belge analizi ve literatür taraması yöntemi ile hazırlanan bu çalışma, özellikle internet teknolojisinde yaşanan gelişmeler ve sosyal medya gibi araçların yaygınlaşması ile güncel ve evrensel bir problem olarak görülmeye başlanan "hakikat" sorunsalının tarihsel bağlamını tartışmayı amaçlamaktadır. Çalıșmanın savı, insanlığın ortak hakikatler etrafında buluşamıyor olmasının siyasal sonuçlarının olduğu ve hakikat tartışmasının günümüz eko-politik atmosferinden bağımsız olmadığı şeklindedir.
\end{abstract}

Anahtar Kelimeler: Hakikat, Postmodernite, Aydınlanma, internet

\section{Transformation of the Concept of "Truth": A Historical-Sociological Review}

\begin{abstract}
"Truth" is among the most frequently used concepts in intellectual networks as well as everyday language. It originates from the fact that practically everyone, from ordinary people to society's leaders, is eager to explain themselves and their positions in respect to the truth in some way. This almost instinctual proclivity has resulted in truth being one of the most often cited concepts throughout history. Yet, throughout history, there have been disagreements and consensus over the path to truth, the source of truth, and the conditions of possessing the truth. This human instinct to possess or at the very least take a side with the truth persists to the present day. Numerous explanations and discussions about the truth continue, with political and social implications. These discussions intensified particularly since the 1970 s and continue to the present day, accompanied by calls for an "end of truth". This study, conducted with document analysis and literature review methods, intends to address the continuing discussion about "truth", which centers on the concept of truth and has garnered widespread attention due to its evident political and social implications. This study argues that humankind's failure to unite around universal truths has political implications. Therefore, one cannot consider the discussion about truth in isolation from the current contemporary eco-political climate.
\end{abstract}

Key Words: Truth, Postmodernity, Enlightenment, Internet

ATIF: Altun, F. (2021). "Hakikat” kavramının dönüşümü: Bir tarihsel sosyoloji denemesi. Medya ve Din Araştırmaları Dergisi (MEDIAD), 4(2), s. 367-379. 


\section{Giriş}

Hakikat, tarih boyunca insanlığı en fazla meşgul eden kavramlardan biri olmuştur. Olayların, eşyaların ve canlıların iç yüzünü anlamakla ilgili çabaların bir biçimde hakikat kavramı ile yollarının kesiştiği ve başta felsefe olmak üzere insan bilgisinin hakikati, tanımlamak üzere işe koşulduğu görülmektedir. Bu çerçevede ortaya çıkan tanımların siyasetten, gündelik yaşama kadar insanlık durumları üzerinde derin etkileri ortaya çıkmıştır.

Türk Dil Kurumu, hakikat sözcüğünü "gerçek" ve "gerçeklik" kelimeleri ile karşılamaktadır ("Hakikat” Maddesi, 2021). Oxford Sözlüğü ise hakikati, herhangi bir şey hakkında, icat edilenlere yahut tahmin edilenlere değil vakalara (fact) dayalı gerçekler olarak açıklamaktadır (Oxford Sözlüğü, 2021). Insanoğlunun hakikatle kurduğu ilişki, yeryüzündeki macerasını tanımlayan kozmik bir ölçüt halindedir. Zira insanoğlu hakikati kimi zaman talep etmekte kimi zamansa reddetmektedir. Bu durum bilginin geçmişe kıyasla giderek fazlalaştığı, hızla "enformasyon/bilgi toplumları" (Castells, 2010)' haline dönüştüğümüz ve adeta bilgi okyanuslarında yüzdüğümüz günümüz dünyasında son derece karmaşık problemlerle insanlığı karşı karşıya getirmekte, hakikatin reddedilmesi olarak anlaşılabilecek toplumsal bir temayül ortaya çıkmaktadır. Özellikle 1960'lı yıllarda Kıta Avrupası'nda gündeme gelen post-yapısalcılık dalgasının etkisiyle, 1970'li yıllarda Amerikan üniversitelerinde tartışılmaya başlanan ve kısa süre içinde tüm dünyayı etkisi altına alan postmodernizm akımı ve onun önermesi olan "hakikatin müphemliği” yaklaşımı, insanlık tarihinde zaman zaman karşışsılmış olan bu bakış açısının en yakın tarihli temsili olarak karşımıza çıkmaktadır. Postmodern felsefecilerin, günümüzde insanlığın hakikatle kurduğu çetrefilli ilişkinin entelektüel tarafını temsil ettikleri düşünülmektedir.

Elbette postmodernite kavramının bir toplumsal eleştiri ve çözümleme aracı olarak ortaya çıkmasının sosyo-politik ve sosyo-kültürel bir bağlamı vardır. Postmodernite, Aydınlanma hareketi ile 17. Yüzyıldan itibaren temelleri atılmaya başlanan Batı modernitesinin doğal bir sonucu olarak karşımıza çıkmıştır ve hakikat bağlamındaki bakış açısının kökeni, Aydınlanmacı aklın, insanoğlunu, "hakikatin kaynağı ve ölçüsü olarak" konumlandırmasından bağımsız değildir. Başlangıçta "les philosophes" olarak anılan felsefecilere özgü görülmüş olan hakikatin kaynağı ve ölçüsü olma durumu, modernitenin yaygınılık kazanması ile sıradan insanların da talep ettiği bir hakka dönüşmüş, bu durum "postmodern durum" olarak anılan tarihsel anı ortaya çıkarmıştır. Bugün post-truth vb. tartışmalarla çerçevelenmeye çalışılan olguların, bahsi geçen vasattan beslendiği düşünülmektedir. Sosyal medyadaki kullanıc etkinliği yaklaşımı ile ortaya çıkan görünümler ise bunun kanıtları gibi.

Elinizdeki çalışma, özellikle internet teknolojisinde yaşanan gelişmeler ve sosyal medya gibi araçların yaygınlaşması ile güncel ve evrensel bir problem olarak görülmeye başlanan "hakikat" sorunsalının tarihsel bağlamını tartışmayı amaçlamaktadır. Bu çerçevede Aydınlanma ile ortaya çıkan "hakikatin kaynağı ve ölçüsü olarak insan" anlayışının, postmodernite ile öngörülmeyen bir aşamaya evirilerek kaynağı demokratikleştirdiği, herkesin kendi hakikatine sahip olabildiği bir dünyanın kapılarının bu anlayışın doğal bir sonucu olarak açıldığı ve "alternatif hakikatler" söyleminin bizzat hakikat kavramını ve olgusunu tartışmaya açıı̆ı iddia edilmektedir. Bu makalenin ortaya çıkmasına imkân sağlayan tez ve fikirler belge analizi ve literatür taraması yöntemleri marifetiyle varlık bulmuştur. Elinizdeki çalışma üç bölümden oluşmaktadır. Aydınlanmacı Zihniyet ve Hakikat Tasavvuru adını taşıyan birinci bölümde hakikatin modernite öncesi bağlamı ele alınarak, Aydınlanma ile birlikte hakikat kavramının algılanışında nasıl bir değişikliğin ortaya çıktığı ele alınacak ve "ölçüsü aşkın olan hakikatten, ölçüsü insan olan hakikate geçiş"in tarihsel dinamikleri açıklanmaya çalışılacaktır. "Postmodern Durum" adını taşıyan ikinci bölümde ölçüsü insan olan hakikat anlayışının nasıl kitleselleştiği ve herkesin kendi hakikatine tutunmayı seçmesinin, modernite ile ortaya çıkan büyük anlatıları nasıl etkilediği tartışılacaktır. “Hakikat"in Dönüşümü adını taşıyan üçüncü bölümde ise değişen hakikat yaklaşımının bireyleri nasıl atomize hale getirerek "kapitalizmin yeni aşaması”"nı başlattığı konusu üzerinde durulacaktır.

\section{Aydınlanmacı Zihniyet ve Hakikat Tasavvuru}

Dünya var olduğu günden beri hiç durmaksızın değişmektedir. Tabiat ve fiziksel çevre, bir taraftan mekânı yöneten kurallar tarafından değiştirilirken diğer taraftan da üzerinde yaşayan canlılar tarafından şekillendirilmektedir. Bu türden değişimin en önemli mimarı hiç şüphesiz ki insanoğludur. İnsanoğlu yeryüzündeki macerasının başlangııından bu yana en temelde iki meseleyi çözmek zorunda kalmıştır; var olabilmek ve varlığını idame ettirebilmek. Şartlar değişse de bu iki mesele insanoğlunun tarih boyunca değişmeyen meseleleri olarak kalmıştır ve tarih dediğimiz olaylar serisinin en önemli dinamikleri olagelmiştir.

Doğa şartları ve vahşi hayvanlar karşısında hayatta kalabilmek, besin temin edebilmek, neslini devam ettirebilmek, ortaya çıkan anlaşmazlıkları çözebilmek gibi meseleler ve bunların çözümleri etrafında maişet/ geçim yolları ve yaşam biçimleri ortaya çıkmıştır. İnsanoğlunun yeryüzündeki macerası sürdükçe biriktirdiği bilgi ve tecrübe artmış, bunlara bağlı olarak kümülatif bir yaşam deneyimi ortaya çıkmıştır. Bu yaşam deneyi- 
mi, en temelde giderek genişleyen ve karmaşıklaşan bir toplumsal ilişkiler ağı şeklinde ortaya çıkmıştır. Bu ağ, tarihin uzun yıllara sâri bağlamı içinde tarıma, tekniğe, yazıya, kültüre, dine, farklılaşan üretim ilişkilerine ev sahipliği yapmış ve insan deneyiminin zenginliğinin bir göstergesi olarak nesilden nesile aktarılarak gelişmeye devam etmiştir. Bu gelişme, bilinen tarihimiz içinde son derece yavaş bir seyirde ilerlemiş ve insan topluluklarının değişimin hızına yetişememesi gibi sorunları genelde olmamıştır. Bu durum son iki yüzyılda değişmiştir. Dünya, sürati giderek artan bir değişim, dönüşüm içindedir ve insanoğlu tarihinde belki de ilk defa değişimin uğultusunu bu denli duymakta, değişen toplumsal topoğrafyayı takip etmekte zorlanmakta ve değişimin hızı karşısında çaresizlik hissetmektedir.

İnsanlığın ortak tarihi için anlamlı bu dönüm noktasının başladığı yer Kıta Avrupası'dır. Amerika kıtasını da etkisi altına alarak büyüyen bu deneyim, tarihsel olarak Aydınlanma (Aufklarung (Alm.) / (Ing.) Enlightment/ (Fr.) Eclaircissement) tecrübesidir. Ahmet Çiğdem'e göre; Aydınlanma denildiğinde 18. Yüzyılda hem Amerika'da hem de Avrupa'da etkili olan, geleneksel olarak İngiliz Devrimi ile bașlatılıp, Fransız Devrimi ile bitirilen felsefi bir hareket ve sürece atıf yapılmaktadır. Bu hareketin temel amacı, insanları köleleştirdiği ve özünde "kötü" olduğu düşünülen hurafelerden, mitlerden ve bunları temsil eden kurumlardan, bu kurumların temsilinde yaşayan eski düzen'den (ancien regime) kurtarmak, özünde "iyi” ve "özgürleştirici” olan "aklın düzeni"ne sokmaktır. Ne var ki bu hareket felsefi bir hareket olmasının yanı sıra özgüllüğünü sadece ve gerçek anlamda felsefi bir karakter taşımamasından almaktadır. Aydınlanma, bir yönüyle hem dolaylı siyasal ve toplumsal sonuçları itibariyle hem de akılsal devrim denilen oluşumun altyapısını oluşturarak "modern toplum"un biçimlenmesine katkı yapmış, (Çiğdem, 1993, s. 11) bize göre büyük oranda politik bir harekettir. Çiğdem, Aydınlanma'yı günümüz politik ve toplumsal yapısına etkileri devam eden 1789 olayları ile kıyaslamaktadır. O'na göre; Fransız Devrimi'nin, çağdaş dünyanın yapısına ve işleyiş tarzına geri çevrilmez formasyonlar katması gibi Aydınlanma da şimdi ve burada kurgulandığı şekliyle, modernitenin bilincini yoğuran bir etken olarak çağdaş dünyanın felsefi ve ontolojik kendini anlamasında inkar edilemez bir rol oynamaktadır (Çiğdem, s. 13). Bu rolü oynayan zihniyetin temsilcileri ise “Edinburgh'dan Napoli'ye, Paris'ten Berlin'e, Boston'dan Philadelphia'ya kültür eleştirmenlerinden, şüphecilerin ve siyasal reformculardan” (Çiğdem, s. 17) müteşekkil, "felsefi bir sistem geliştirme konusunda ne istekli ne de başarılı, söylediklerinin bir cemaat-içi söylem olmasından çok, kamuya ulaşmasından yana, dolayısıyla belli bir felsefi dil kurma yerine, var olan dili felsefe için araçsallaştıran, ne ateist ne de teist ama bazen deist bazen pagan, temel inancı insanın yeryüzündeki hayatının kusursuzlaştırılması dışında da bir inancı olmayan, korku ve miti aşılması gereken uğraklar olarak görüp, kendileri birer korku ve mit imgesi haline dönüşmüş “aydınlanmış despotlara” bir tür put-kırıcı gözüyle bakan, kimi Diderot gibi ölünceye kadar kendi ilkelerine ve zeminine sadık, kimiyse Voltaire gibi her an ve tehlike karşısında ilkelerinden vazgeçmeye, hiç değilse gözden geçirmeye hazır, politik otoriteyle ne barışık ne de büsbütün küs, kah 18. Yüzyılın “yaramaz çocukları” kah "akıl imparatorluğunun saygıdeğer üyeleri "les philosophes”dir (Çiğdem, s. 16-17).

Peter Gay, bu filozofların, içinde yaşadıkları zamanın ve toplumun değer yargıları ile tam bir uyum içinde olmadıklarını bazı örnekler üzerinden aktarmaktadır. Buna göre; Aydınlanma felsefecileri çilecilikten nefret etmekte ve şehevi duyguları olumlamaktadır. Rousseau'nun hayatı boyunca pişmanlığını çektiği mazoşistik zevkleri olmuştur; Hume'un Fransa'da gayrimeşru bir ilişkisi vardır; genç Benjamin Franklin “düşük kadınlarla entrikalara karışmış” ve gayrimeșru bir çocuk sahibi olmuştur; Diderot metresini bazı șeylere alıștırmak düşüncesiyle pornografik bir roman yazmıştır, Le Mettrie bir oburdur. Prusya sarayında bozuk bir pasta yedikten kısa süre sonra ölmüştür ve patlayarak öldüğü dedikodularının arkası kesilmemiştir; Voltaire'in yeğeni ile yaşadığı uzun ve tutkulu aşk ise 18. Yüzyılın en iyi saklanan sırlarından biri olmuştur (Gay, 1966, s. 8-9).

Aydınlanma hareketini ortaya çıkaran, içeriklendiren, taşıyıcılığını yapan, pek çoğu gerçek anlamda filozof bile olmaya ve birçoğunun kişisel hikayeleri nedeniyle de topluma tam olarak uyum sağlayamadıkları anlaşılan, gevşek, disiplinsiz bir koalisyondan (Çiğdem, 1993, s. 16-17) oluşan bu topluluğu birbirine bağlayan ve ortak hareket etmelerini sağlayan bir program mevcuttur. Bu program Çiğdem'in Gay'den aktardığı cümlelerle;

Sekülerizm ve insanlık, kozmopolitanlık ve bir yığın formlarda (keyfi iktidardan bağımsız hareket etme, konuşma, ticaret, bireyin yeteneklerini gerçekleștirme, estetik yaratım, bir kelimeyle, herhangi birinin dünyadaki yolunu kendisinin bulması hürriyeti) ortaya çıkan hürriyet programıdır (Çiğdem, s. 16-17).

Bahsi geçen hürriyet programının en önemli öğesi ise geçmişten ve özellikle de Hıristiyanlıktan keskin bir kopuştur. Gay bu kopuşun iki önemli motivasyonu olduğunu düşünmektedir. Bunlar eleştiri ve güçtür. Buna göre; Aydınlanma çağı filozofları, otonomi için diyalektik bir mücadele vermişler ve tevarüs ettikleri iki geçmiş olan Hristiyan ve pagan geçmişi asimile etmeye çalışmışlardır. Bu iki geçmişi birbirlerine düşürerek kendi bağımsızlıklarını güvence altına alabileceklerini düşünmüşler, özellikle de Hıristiyan mirası ile hesaplaşmak için klasik antikitenin putperestliğine bağımlı yeni bir putperestlik icat etmişlerdir. Bu putperestlik Hıristiyan dogmasından olduğu kadar klasik düşünceden de özgürleşmiş bir modern zaman putperestliğidir (Gay, 1966, s. XI). 
Gay'in "modern paganlık" olarak adlandırdığı bu program, sonraları Aydınlanma olarak adlandırılacak hareketin hem müntesiplerini hem de geniş kitleleri ortak bir zeminde buluşturmayı başaran cezbedici bir kavramsal paketleme olarak hürriyet fikrini kitlelere yaymayı başarmıştır. Son derece örgütlü ve siyasal ajandası belirgin olan bu hareket, yüzeyde felsefi, düşünsel bir hareket gibi görünerek, ruhban sınıfı ve aristokrasinin hakimiyeti ile karakterize olan Avrupa'nın o dönemdeki hâkim politik-toplumsal yapısına yönelik dönüştürücü politik ajandayı başarılı bir biçimde gizlemiştir. Hareketin başını çeken “les philosophes”in başta burjuvazi olmak üzere örgütlü yapılardan hatırı sayılır bir himaye ve finansman desteği aldığı görülmektedir.

Öyle ki, Ulrich Im Hof'a göre, aydınlanma sadece düşünürlerin, filozofların, yazarların ve zamanla uyum halinde ve onun içinde etkin olan tek tek herkesin ilgilendiği değil, özellikle örgütlü ve örgütsüz toplulukların da ilgilendiği bir konu olmuştur. Çoğunlukla dost çevreleri olarak başlayan bu topluluklar ya zamanla akademi vb. yapılar haline dönüşerek kurumsallaşmışlar yahut mason locaları gibi halihazırda örgütlü halde bulunan yapıların desteğini arkalarına almışlardır. Akademiler ve cemiyetler başta olmak üzere zamanla örgütlü hale gelen yapılar hızla büyümüş, örneğin Almanya'da 18. yüzyıl başında sadece iki olan akademi sayısı yüzyıl sonunda bir düzineyi bulmuştur. Benzer şekilde Avrupa'da kamu yararına çalışan ilk cemiyet 1723 yılında Edinburgh'da kurulmuşken, Fransız Devrimi'ne kadar Avrupa ve Avrupa dışında olanlarla birlikte bu sayı yüz elliyi bulmuştur.

Bunlara ek olarak salonlar da Avrupa'nın düşünce ikliminin belirlenmesi noktasında hatırı sayılır işlevler görmüşlerdir. 18. Yüzyıl sonunda başta İngiltere, Fransa ve Almanya'dakiler olmak üzere Avrupa'nın etkin başkentlerinde filozofların himaye edildiği ve tartışmalarına zemin sağlayan birçok salonun varlığı bilinmektedir. Salon kültürünün başladığı Fransa'da 17. Yüzyıl sonlarında soylu ve büyük burjuva kadınlarının, toplumsal iletişimin günlük boşboğazlıklarına dalarak değil, belirli içerikleri olan konular hakkında tartışarak gevezelik etmek ve konuşmak için özel kişileri, arkadaşları ve tanıdıkları, belirli tarihlerde evlerindeki salonlarında kabul etmeye başlamaları ile ortaya çıkan bu gelenek, 18. Yüzyılda bütün Avrupa'yı etkisi altına almışıır. Yüzyıl sonunda Almanya'da bazıları Yahudi kadınlar tarafından yönetilen, "önemli genç delikanlıların ve genç erkeklerin hepsinin, tıpkı bir sihirle içine çekildiği” pek çok salonun olduğu bilinmektedir. Salonlar edebiyat kulüplerine, bunlar da örgütlü okuma gruplarına kaynaklık etmişlerdir (Hof, 1995).

Pek çok farklı entelektüel kişiliğin, "eski düzen” ile mücadele fikri etrafında bir araya geldiği bu filozoflar koalisyonuna hem zihinsel hem finansal hem de mekânsal anlamda destek olan ve fikirlerinin taşıyıcılığını yapan yapılar ise çeşitli olmuştur. Bunların başıcaları cemiyetler, akademiler, salonlar, edebiyat kahveleri, okuma toplulukları, gönüllü hayır cemiyetleri ve ekonomik topluluklar, masonlar, dergiler ve kitaplardır (Hof, 1995, s. 102-148). Avrupa, bahsi geçen bu yapıların finansal desteği ve himayesi altındaki düşünürlerin çabaları ile kısa sürede büyük bir değişim, dönüşüm süreci içine girmiştir. Bu nedenle Aydınlanma hareketini ciddiyetle koordine edilen ve devasa kaynaklarla finanse edilen uluslararası politik bir hareket olarak tanımlamak mümkün görünmektedir.

Bu hareketin özellikle 1789'da elde ettiği ilk büyük siyasi başarıdan sonra Avrupa'daki bütün geleneksel yapıları birer birer hedef aldığı ve değiştirdiği tarihin iyi bilinen vakalarından biridir. Avrupa'da büyük bir devrimler çağını açan olaylardan sonra Kilisenin ve aristokrasinin iktidarı sona ermiş, burjuvazi Avrupa toplumsal yapısının hâkim sınıfı haline dönüșmüş ve bütün kurumları ve toplumsal mekanizmalarıyla bugün bildiğimiz modern Batı medeniyeti ortaya çıkmıştır. Teoman Duralı'ya göre; 'bengisu'yunu Doğaüstü pınardan temin etmediğini öne sürerek 16. yüzyılın sonlarından itibaren tarih sahnesine çıkan ilk ve tek medeniyet, bahsi geçen Aydınlanma hareketinin kaynaklık ettiği bu medeniyettir. Bu medeniyet baştan aşağı felsefeleşmiş bir medeniyet olmakla birlikte, felsefenin ana odağı olan metafiziğini, özellikle 17. Yüzyılın sonlarından itibaren, din temeline dayandırmayı reddetmiştir. Hayatın en üst değerleri olan ve aslen dini terimler olan akıl ve vicdanı başlı başına bağımsız birimler olarak ele almış ve kendinden menkul hakikatler olarak kabul etmişlerdir. Böylece vahiy çeşidinden doğaüstüne uzanan bağları kesmişlerdir. Bu tasavvur için akıl neye dayanır sorusunun cevabı yine aklın kendisidir (Duralı, 2000, s. 40). Bu aşamadan sonra "hakikatin kaynağı da ölçüsü de Tanrı değil, insanoğlu" olarak kabul edilmiş ve bu kabulün insan yaşamı üzerinde dramatik etkileri ortaya çıkmaya başlamıştır.

\section{1. Ölçüsü Aşkın Olan Hakikatten, Ölçüsü İnsan Olan Hakikate}

Modernite öncesi dünyada insanların hakikatle kurdukları ilişkinin en önemli parametresi doğada ve insan yaşamı içinde çalışan bilgiye erişebilmek olmuştur. Çünkü insanoğlunun açlık ve hastalıklarla mücadele edebilmesi, barınak inşa edebilmesi, şehirler kurarak ve toplu yaşamanın yollarını keşfederek güvenliğini temin edebilmesi, ürünlerini koruyabilmesi ancak tabiatta çalışan bilgiyi elde edebilmesi ile mümkün olmuştur. Aynı şekilde insanoğlu, toplumsal tecrübeye ve tarihsel örüntülere dayanan bilgiyi toplayarak kendisine bir yol haritası belirleyebilmiş ve böylece gereksiz savaşlardan ve çatışmalardan kaçabildiği kadar kaçarak kaynaklarını ve enerjisini hayatta kalma mücadelesine yönlendirebilmiştir. Öte taraftan modern insanın, hakikatle son derece dolaylı bir ilişkisi vardır. Bunun en önemli nedenlerinden biri; insanların, modern üretim ilişkileri içinde 
ortaya çıkan son ürün ile emekleri arasındaki bağlantıyı kurmaktan yoksun bırakılmış olmalarıdır. Marx'ın “yabancılaşma” olarak adlandırdığı bu süreç insanoğlunun hangi eylemlerinin anlamlı, yararlı sonuçlar ürettiğini hangi eylemlerinin ise yıkı c sonuçlar ürettiğini görmesini zorlaştıran bir faktördür. Yıkıcı eylemleri için hemen bedel ödemeyen insan, emeğinin karşılığı olarak hak ettiği tatmin duygusunu yaşamaktan da büyük oranda uzaklaştırılmıştır. Karmaşık iş süreçleri içinde emeğinin tam olarak neye tekabül ettiği bilgisinden yoksun bırakılmaktadır. Bir kalem fabrikasından çalışan işçi, son ürün olarak ortaya çıkan kalemin hangi parçasını ürettiğini bilemediği için, son ürüne yani kaleme baktığında, bunu benim eserim diyememektedir. Bu durum insanları sadece eylemlerinin sonuçlarından habersiz hale getirmemekte aynı zamanda hakikatle bağlarının da zayıflamasına neden olmaktadır.

İnsanoğlu, tarihin başlangıcından itibaren hakikatin ya aşkın güç tarafından kendisine verildiğini yahut hakikatin kaynağının aşkın bir güç değil yine kendisi gibi insan yahut insanlar olduğunu düşünmüştür. Her iki ilişki biçiminde de hakikat insan yaşamını belirleyen ve ona nasıl yaşaması gerektiğini söyleyen temel başvuru kaynağı olarak dini/manevi duygularla ilişkili olarak varlığını sürdürmüştür. Hakikatin aşkın güç tarafından verildiğine inanan insanlar, ilkel dinlerden başlayarak semavi dinlere kadar uzanan kurumsal dinin sınırları içinde hareket etmişlerdir. Öte yandan hakikati yine kendisi gibi insanlardan aldığını düşünenler ya hakikati elinde tuttuklarını düşündükleri insanlara zaman içinde tanrısal özellikler atfetmeye bașlamış yahut bu insanlar bizzat Tanrısal bir role talip olmuşlardır. Pozitivizm gibi kendisini tamamen akılla açıklayan bir felsefi görüşün, bizzat kurucusu tarafından, Orta Çağ’da Hıristiyanlığın oynadığı rolü endüstri toplumunda oynamasını bekleyerek, “insanlık dini” adında yeni bir din olarak kurgulaması (Wernick, 2003) antik Mısır'ın “insan tanrı”ları olan Firavunlar, tarihte zaman zaman ortaya çıkan ve takipçilerinin ilahi güç atfettikleri kimi siyasi/askeri figürler, günümüzde hatırı sayılır kalabalıkları peşinden sürükleyen New Age dinler yahut adeta dinsel topluluklara dönüşen kimi hayran kitleleri, bahsi geçen durumun örnekleri arasında yer almaktadır. Modernitenin ortaya çıkışından önce, Hıristiyanlığın, özellikle Orta Çağ'daki en güçlü olduğu dönemden itibaren Avrupa üzerindeki etkisi ve diğer iki semavi din olan İslamiyet ve Museviliğin dünyanın geniş coğrafyalarını ve nüfusunu ilgilendiren etkileri ise tartışılmazdır. Hakikatin insanlara, insanlardan bağımsız aşkın bir merci tarafından doğrudan yahut doğanın içine gizlenmiş olarak verildiğinin kabul edildiği modern öncesi dünyada, hakikatin zamana, şartlara, kültüre ve teknolojiye göre biçimsel farklılıklar taşısa bile özde aynı kaldığı kabul edilmektedir. Zira ne aşkın olanın mahiyeti ne de doğanın yasaları değişmektedir. Ancak Aydınlanma hareketinin tüm dünyadaki askeri, siyasi başarılarından sonra tüm dünya sathında hakikatin kaynağı ve ölçüsü olarak aşkın olanı gören anlayış, tüm dünya sathında aşınmaya başlamıştır. Bunun yerine Aydınlanmacı aklın üretmiş olduğu "hakikatin kaynağı ve ölçüsü olarak insan" anlayışı yerleşmiştir. Bu kabulün en dolaysız sonucu "zamana ve şartlara göre değişen hakikat” anlayışının zemin kazanmaya başlaması olmuştur. Çünkü insanoğlu içinde yaşadığı şartlara ve zamana göre değer yargılarını değiştirebilen bir canlıdır ve bir asır önce yaşayan insanlar için asla kabul edilemez görünen davranışların yahut fikirlerin bile bir asır sonrasında yaşayan insanlar için makul, hatta erdemli davranışlar yahut fikirler olarak kabul edilir hale geldiğine dair sayısız tarihsel kanıt mevcuttur.

\section{3. "Postmodern Durum"}

Modern dönemde insanoğlunun hakikatle ilişkisinde ortaya çıkan bu değişim giderek rafine hale gelmiş ve 1970'li yıllardan itibaren sanatlarda ve mimaride tartışılmaya başlanan (Kumar, 2013) postmodernite söylemi ile kristalize olmuştur. Postmodernite, içinde yaşadığımız çağın tanımlanması en zor kavramlarından biri olarak tarihe geçmiştir. Featherstone, postmodernizmin hem moda hem de tanımlanması son derece zor bir kavram olarak yerli yersiz kullanmasının sığ bir entelektüel heves olarak yaftalanabileceğini ifade etmektedir. Featherstone kavramın etrafındaki sis bulutunu şu sözlerle tanımlamaktadır:

“Modern Yerleşik Düşünceler Sözlüğü’nün de onayladığı gibi, “Bu sözcüğün hiçbir anlamı yoktur. Olabildiğince sık kullanın” (Independent, 24 Aralık 1987). Bundan on yıldan fazla bir süre önce, 1975 yılının Ağustos ayında başka bir gazete "postmodernizmin öldüğünü ve şimdi post-postmodernizmin gündemde" olduğunu ilan etmişti. Postmodernizm geçici bir modaysa eğer, bu modanın yaygınlığından kimin sorumlu olduğundan kuşku duymayan eleştirmenler de vardır: Alanı politekniklerde ve üniversitelerde masa başında araştıran günümüzün ücretli teorisyenleri birtakım akımlar icat etmek zorundadır; çünkü mesleki ilerlemeleri bu icatlara bağımlıdır: En az madencilerinki ya da balıkçılarınki kadar. Ne kadar çok akım uydururlarsa o kadar başarılı olacaklardır. Başka eleştirmenlere göre ise bu stratejiler sadece entelektüel ve akademik alanlara özgü hamleler değildir; bu stratejiler “çağdaş kültürün orta yerindeki hastalık”ın açık seçik işaretleri ve barometreleridir. O nedenle "şimdilerde postmodernizm olarak bilinen kültürel ve estetik eğilimi -sanat ve mimari de, müzik ve sinemada, tiyatro ve kurmacadaki eğilimi- Batı dünyasını sürükleyen bugünkü politik reaksiyon dalgasının bir yansıması olarak kavramak için çok çaba harcamak gerekmez" (Featherstone, 2013).

Giddens ve Sutton'a göre:" postmodernite, 1970'li yıllarda gelişmeye başlayan, moderniteyi izleyen, net bir tanımı yapılamayan, çoğulcu ve kendisinden önceki modernlikten sosyal yönden farklı bir tarihsel dö- 
nemdir. İlk olarak sanat ve kültür alanında ortaya çıkan postmodernliğin sosyal teoride "postmodern dönüş" adıyla adeta moda haline dönüşmesi ise 1980'lerin ortalarında gerçekleşmiştir. Mimaride Londra'daki Lloyd's binası gibi tuhaf binaları ortaya çıkarak bir tarz gelișmiş, sinemada David Lynch gibi yönetmenlerin tuhaf dünyaların, eski moda romantizmle, ahlak anlatılarılla, ölçüsüz şiddet ve cinsel 'sapkınlık'ın birleştirilmesi ve tarihsel dönemlerin iç içe geçirilmesiyle oluşan karmaşık anlatıları olumlanmış, kültürün ve sanatın bir çok alanında bu türden eğilimlere yol verilmiş, en sonunda $1980^{\prime}$ 'li yıllardan itibaren bu akımın etkileri sosyal bilimlerde de görülmeye başlanmış ve bütün bu değişimlere "postmodern" adı verilmiştir (Giddens \& Sutton, 2018).

Roland Robertson'a göre; 1950'lerin sonu ve 1960'ların ilk yarısında modernleșme tartışmaları ile birlikte postmodernite yahut postmodernleşme tartışmaları da ortaya çıkmıştır. Bu durum, modernite-postmodernite tartışmalarının bir parçası haline gelen post-endüstri tartışmalarını da beslemiştir. Robertson, postmodernite sorununun moderniteden sonra bir şey olmalı anlayışı ile ortaya çıktığını ifade etmektedir (Robertson, 1993). Alan Swingwood ise postmodernlik kavramını, tarihsel açıdan, sanayi üretimi, sınıfsal yapı ile çıkarların gerilemesini, bunun karşılığında tüketimcilik, teknolojik iletişim tarzları ve farklılaşmış statü yapısını vurgulayan post endüstriyel toplum tezi ile bağlantılı olarak açıklamaktadır. Buna göre; postmodernlik, modern kültürel alanı toplumsal alandan ayırdığı ve kitle kültürü ile eleștirel, 'yüksek' kültür arasında temel bir ayrılığa yol açıı̆̆ı halde; popüler/ kitlesel 'meta' kültürünü modernist estetiğin biçimleri ile birleştirmektedir (Swingwood, 2014).

Madan Sarup'a göre postmodernizm, baskıcı, bütünlüklü, tek tipleştirici totaliter bir siyaset yerine, çoğulcu, özgürlükçü, açık bir demokrasinin gereği üzerinde durmaktadır. Buna göre; Marksizmin de bir parçası olduğu "Aydınlanma tasarısı" ile birlikte anılan ilerlemenin kesin doğruluğu savunusunun yerini artık olumsallık ve değişebilirlik bilinci almıştır. Sarup, sanatın değişik alanlarında postmodernizm ile birlikte anılan kilit konumdaki özellikler arasında; sanat ile gündelik yaşam arasındaki sınırların silinişi, seçkinci kültür ile popüler kültür arasındaki hiyerarşik ayrımın çöküşü, biçemsel derlemeciliğin (seçmeciliğin) yükselişi, kodların karışarak kırmalaşması, 'parodi', 'pastiş̧, 'ironi' ve 'oyunculuk'un ve 'derinliğin değil yüzeyin önemi üstünde duran bir modelin’ yükselişi gibi olguları sıralar (Sarup, 1995). Sarup, 1960’larda New York’ta yaşayan sanatçılar ve eleştirmenler arasında ortaya çıkan ve ileri kapitalist kültürde, özellikle de sanat dallarında gözlenen ve postmodernlik kültürü olarak görülebilecek bir hareketin adı olarak formüle edilen bu terimin, 1970'li yıllardan itibaren Avrupalı kuramcıları derinden etkilediğini aktarır. Bunların başında Jean-François Lyotard gelmektedir. Lyotard, postmodern teorinin kurucu eseri kabul edilen Postmodern Durum'da modern çağın büyük anlatılarına, bilim sayesinde insanlığın özgürleșeceği beklentisine ve modern anlatının pek çok öncülüne saldırıya varan eleştirilerde bulunmuştur (Sarup, 1995, s. 158).

Lyotard, temelde bilgi ile hakikat ilişkisini anlattığı bu eserde, günümüzde gerçekliğin büyük oranda performativite tarafından belirlendiğini ifade etmektedir. Buna göre; bağlamın kontrolü, yani ister insan olsun ister doğa olsun bağlamı oluşturan elemanlara karşı gerçekleştirilen performansların iyileştirilmesi, bir tür fiili meşrulaştırma biçimidir. Bu kontrolü sağlayan şey ise tekniklere sahip olunmasıdır. Teknikleri güçlendirmek suretiyle gerçeklik yani adil görünmek, haklı çıkmak gibi durumlar yaratılabilir. Bu da esasen güç yoluyla meşrulaştırmadan başka bir şey değildir. Lyotard'a göre betimleyici olsun, buyurucu olsun bir söylemin performativitesi, göndergesi hakkında elde bulunan bilgiyle doğru orantılıdır. Böylece günümüzde gücün artması ve kendi kendini meșrulaştırması, çeşitli bilgilerin üretimi, belleğe kaydı, erişilebilirliği ve iş görürlüğünden geçmektedir (Lyotard, 2019) ki bu durum esasen bilginin "hakikat" kavramından koparak toplumsal kontrol aracına dönüşmesi noktasında modern toplumların ulaştığı aşamayı tariflemektedir.

Lyotard'ın bu eserinden sonra bilgi ve hakikat konusundaki entelektüel tartışmalar giderek yoğunlaşmış ve artık yeni bir dönemde olduğumuz hissi akademik mahfillerde yaygın kabul görmeye başlamıştır. Bu çerçevedeki "hâkim görüş, postmodernite ile imlenen dönemin, moderniteden keskin bir kopuşa işaret ettiği yönündedir. Oysa Sarup, estetik bir öz bilinç ya da kendini bilme yanında estetik bir yoldan kendi üstüne düşünmenin yükselişi; eşzamanlıık ile kurgu lehine anlatı yapısının yadsınışı; gerçekliğin paradoksal, belirsiz, açık uçlu doğasının araştırılışı; bütünlüklü bir kişilik yapısı tasarımının, Freudcu "bölük pörçük" özne ("kırık dökük" kişilik) üstüne yapılan vurgu lehine olumsuzlanışı gibi modernizme ait olduğu düşünülen özelliklerin, postmodernizm söz konusu olduğunda da aynı şekilde tekrarlandığını ifade etmektedir. Bu çelişkiyi Terry Eagleton da tekrarlamakta ve bu durumu "postmodernizmin tuhaflığı" olarak açıklamaktadır. O'na göre postmodernizmin, kültürel açıdan bakıldığında tikel bir tarihsel döneme aitmiş gibi görünmesine rağmen, felsefi açıdan bakıldığında uzun bir süredir geçerli olması gerekmektedir. Eagleton, bu durumda "post" ile ifade edilenin, tarihsel bir sınır çizgisinden ziyade teorik bir sınır çizgisi olması intimalini ortaya atar (Eagleton, 1999). Zygmunt Bauman da benzer bir yorumda bulunarak, her zaman bir şeyin "post-"u olmanın, modernitenin ayrılmaz bir parçası olduğunu iddia eder. O'na göre; yüz yıl önce modern olmak, mümkün olan “en üst mükemmellik aşamasına" ulaşmaya çalışmak demekken, bugün gelişme arzusunun sonsuzluğu, ulaşılabilecek nihai bir hedefin yokluğu ve hatta böyle bir isteğin bile olmaması anlamına gelmektedir. Bu dönem, Bauman’a göre 
yanlış şekilde postmodernite olarak adlandırılmaktadır. Zira bu dönemde modernite nihayete ermiş değildir. Sadece moderniteye içkin formlar akışkan hale gelmiş, değişmeyen tek şeyin değişim, kesin olan tek şeyin de belirsizlik olduğu hissi yaygın hale gelmiştir (Bauman, 2017).

Bazı düşünürlerin postmodernitenin, aslında modernitenin bir devamından başka bir şey olmadığını iddia etmeleri ve buna ilişkin ikna edici kanıtlar ortaya koyuyor olmaları, postmoderniteyi Batı medeniyetinin çöküşü, modernitenin iflası gibi tamlamalarla açıklamaya çalışan değerlendirmelerin yaygınlığı ile derin bir çelişki ortaya koymaktadır. Gerçekte de postmodernizmin ortaya çıktığı şartlar ve hizmet ettiği politik iklim göz önüne alındığında yeni bir konseptten ziyade, bir yeniden paketleme girişimine daha çok benzediğini teslim etmek gerekmektedir. Kronoloji, bağlam ve politik çıtılar, postmodernizmi, modernizmden ya da başka herhangi bir şeyden ayırabilmek için elimizdeki en iyi araçlar olarak görünmektedir. Fredric Jameson'ın da benzer bir noktadan hareket ederek postmodernitenin, moderniteden önemli farklılıkları olmasına rağmen daha büyük süreklilikleri içerdiğini iddia etmektedir. Jameson, 1984’te kaleme aldığı “Postmodernism, or The Cultural Logic of Late Capitalism" adlı makalesinde, günümüzde kapitalizmin en son aşamasında bulunduğumuzu, bu aşamanın yeni bir kültürel mantığa büründüğünü ve bu mantığın adının Postmodernizm olduğunu ifade etmektedir. Başka bir değişle kültürel mantık değişmiş olsa da altta yatan ekonomik yapı, kapitalizmin erken formu ile aynen devam etmektedir. Jameson'a göre kapitalizm, hayatiyetini devam ettirebilmek için her zaman başvurduğu numaraya başvurmakta ve üstte yatan kültürel mantaliteyi değiştirerek varlığını garanti altına almayı hedeflemektedir (Jameson, 1991).

Jameson'un açılımına benzer bir açılım İrfan Erdoğan'ın analizinde görülür. Ona göre; her ne kadar postmodernizm, kapitalizmin endüstriyel modernleşmeden öte yeni bir çağını işaretliyor olsa da var olan sistem yine de kapitalizmdir. Modernlik, endüstriyel toplumların yapısını, postmodernlik ise post-endüstriyel kapitalist toplum yapısını imler. Ayrımların adları değişmiş olsa da ayrımlar yerlerindedir. Nasıl ki endüstriyel devrimle ortaya çıkan kapitalist toplumlar, sosyal sınıfları ortaya çıkardılarsa, postmodernizmde de silikleșen sosyal sınıfların yerine birey, yaş, cinsiyet, grup gibi elemanlar ve onların kültürleri geçmiştir ve kültür temel belirleyici faktöre dönüşmüştür. Ekonomik alanda kapitalizmin pazarı ve üretim biçimlerini daha küçük parçalara ayırması, büyük firmalar yerine taşeronların kullanılması, sendikaların ortadan kalkması yahut fabrika içi birimlere dönüşmesi söz konusudur. Siyasal alanda ise geniş devlet kurumları yerine, küçük devlet kurumlarına, devletin ekonomiye karışmamasına ve özel teşebbüse dayanan bir formasyon ortaya çıkmıştır (Erdoğan, 2000). Böylece giderek taşeronlaşan üretim alanında emek sömürüsü ve işçilerin haklarını arayacakları mekanizmaların daha da aşınması gündeme gelmektedir. Bu gelişmelere siyasal alanda devletin meşruiyetini sorgulayan ve küçülmesini yücelten bakış açıları eklendiğinde, kapitalist sirayetin hız kazanmasının ve meşruiyetinin sorgulanamaz hale gelmesinin postmodernitenin temel karakteri olduğunu söylemek abartılı olmayacaktır.

Postmodernitenin, modernite ile bahsi geçen devamlılık ilișkisi, hakikat söz konusu olduğunda da geçerli olmakta ve Aydınlanma ile başlayan hakikatin dönüşümünün, modernite ile kurumsallaştığı, postmodernite ile yeni aşamaya geçtiği izlenebilmektedir.

\section{4. “Hakikat”in Dönüşümü}

Modernite, Avrupa şartlarında 19. Yüzyılda zirve noktasına ulaşan bir değişim- dönüşüm sürecine geriye dönük olarak verilen bir addır. Bu süreci bașlatan tarihsel dönüm noktasının Aydınlanma olduğundan yukarıda bahsettik. Modernite özelinde üzerinde ortaklaşılan en önemli husus bu değișim-dönüșüm sürecinin arka planında yer alan toplumsal sınıfın burjuvazi olduğu ve modernitenin bütün özelliklerinin burjuvazi ile olan illiyet ilişkisi içinde şekillendiğidir.

Modernite öncesi dünyada, Avrupa'nın toplumsal yapısı Kilise'nin ve soyluların öncülüğünde örgütlenmiş, bu iki yönetici sınıf dışında kalanların toplumun gidişatı hakkında söz hakları son derece zayıf olmuştur. 15. Yüzyıldan itibaren coğrafi keşiflere bağlı olarak zenginleșmeye başlayan ve sonradan burjuvazi olarak anılmaya başlanacak toplumsal sınıf, bu durumun değişmesi için entelektüel bir hareketliliği finanse etmiş ve gerçekten de bu hareketlilik Avrupa'nın çehresini birkaç yüz yıl içinde değiştirmiştir. Aydınlanma olarak anılan bu dönem toplumsal hareketlere de kaynaklık etmiş ve 1789 yılında gerçekleşen Fransız Devrimi ile Avrupa'nın geleneksel yapısı parçalanmaya başlamıştır. Bir burjuva devrimi olarak anılan Fransız Devrimi'nden sonra toplumsal sınıflar da yeniden şekillenmiştir. Daha önce ruhbanlar, soylular ve halk şeklindeki geleneksel üçlü tasnifte kendisine yer bulamayan burjuvalar, ruhbanları ve soyluları yerlerinden ederek en güçlü toplumsal sınıf haline dönüşmüşlerdir. Bahsi geçen çalkantılardan doğan modernite, burjuvazinin tartışmasız liderliği ile ilişkili bir dönemdir.

Burjuvazi, toplumsal yapıda saygın bir yer edinmek üzere geleneği ve bildik toplumsal şablonları parçalayıp yeni bir dünya inşa ederken, yaratmaya çalıştığı alternatif dünya konusunda bir hayli tutkulu davranmış- 
tır. William R. Everdell’a göre; 19. yüzyıl kafaları başka hiçbir konuda anlaşamadıkları halde, sivri köşelerden, çıkıntılardan hoşlanmamak konusunda hemfikirdiler. Ontolojik süreklilik talebi, entelektüellerin kavram dağarına “durağanlık”, "gelişim”, “düzensizlik”, "geçiş”, “ilerleme”, “evrim” gibi kelimelerle birlikte "çöküş”, "çürüme” gibi kavramları sokmuştur. Bu durum 19. yüzyıl Batı düşüncesinin o denli belirgin bir özelliği halindedir ki süreklilik fikrini kabul etmeyen bir düşüncenin başarılı olma şansı yoktur (Everdell, 2007). Bilimsel devrim ve Endüstriyel Devrim'in (Küçük, 2018) yardımı ile maddi planda işlerin eskisinden çok daha iyiye gittiğine kitleleri ikna edebilseler de bu kabulün toplumsal yapıya, sanata, felsefeye, siyasete ve insan yaşamını ilgilendiren diğer alanlara sirayet etmesi kolay olmamıştır. Toplumun ikna edilmesi ve kitlelerin ortak bir hedef doğrultusunda örgütlenmesi için çok çalışılması gerekmiştir.

Bu bağlam içinde eserlerini veren ilk modernlerin hepsi, başarıyı bir ideal olarak görürken, topluma "büyük hakikatler" vazetmekten de geri durmamışlardır. Büyük anlatılar olarak adlandırılan bu hakikat öbekleri, toplumu ve tarihi ilerlemeci bir mantıkla okumuş, eski olan her şeyi kötü olarak etiketlemiştir (Habermas, s. 3). Söz konusu bağlam içinde ilk modernlerin en önemli talepleri ilerleme ve ahenk olarak ortaya çıkmış, vazettikleri büyük hakikatler bu iki temel üzerinde yükselmiştir. Buna göre Marx, toplumların; ilkel, kölecil, feodal, kapitalist aşamalardan geçerek sosyalist/komünist aşamaya ulaşacağını, Comte ise teolojik ve metafizik aşamalardan geçerek pozitivist aşamaya ulaşacağını yazmıştır. Moderniteyi karakterize eden ilerlemeci anlayışı temsil eden bu tarihsel anlatılar karşısında, moderniteye içkin ahenk fikrini öne çıkaran Durkheim gibi düşünürler yer almış, onlar da toplumu işlev üzerinden anlayan büyük anlatılar vazetmişlerdir.²

Bu ilk dönemin disiplinli modernlerinin çabaları karşılık görmüş ve 20. yüzyılın ortalarına gelindiğinde (iki dünya savaşından sonra) artık modernite tüm dünyada rakipsiz bir toplumsal, siyasal ve felsefi öneri haline dönüşmüştür. Ekonomik başarıların ardından siyasal başarılar gelmiş, yeni dünyayı kucaklayan yeni nesiller ortaya çıkmış, yeni bir yaşam biçimi doğmuş ve bütün bu görüngülerin eşliğinde modernitenin, kendisinden önce gelen hemen hemen her şeyi tasfiye ettiğine dair bir inanç ortaya çıkmıştır. Bu aşamanın devamı Batı'ya ait bu deneyimin "modernleşme" adı ile paketlenerek tüm dünya sathına yayılmaya başladığı aşamadır (Eisenstadt, 2007).

20. yüzyılın sonlarına doğru gelindiğinde modernitenin açmazları süpürüldükleri halı altlarından çıkmaya ve kendilerinden giderek artan oranda söz ettirmeye başlamışlardır. Yalnızlık, anlam kaybı, büyünün yitimi, tüketimin pençesindeki insanlık halleri, toplumsal bağların ve ailenin çözülmesi, insan ilişkilerinde sahiciliğin ortadan kalkması ve çıkar ilişkilerinin bütün insani ilişki biçimlerine sirayet etmesiyle birlikte modernitenin ağır eleștirilere maruz kalmaya başlaması söz konusu olmuş ve Batı içinde modernlik sonrası çağın (post-modernite) içinde olduğumuza dair konuşmalar başlamıştır. Bütün özellikleri ile Batı tecrübesini yansıtan postmodernite kavramı, ortaya çıktığı ilk andan itibaren yoğun tartışmalara kaynaklık etmiş, bu tartışmaların azımsanamayacak bir kısmı tanımlama çabalarına ayrılmıştır. Bu çerçevede "karma bir başkaldırı üslubu, söylemin bir merkezden idare edilmeyiși, benlik ve öteki, yüksek ve düşük kavramlarından sıyrılış, dönemlerin birbirine karışması, her şeyin birbirine geçirilmesi, bir sanat eserinin kendisini oluşturan unsurlara ayrılabileceğine dair kırılgan bir ısrar, Chevrolet Impala'nın yerini Apple Macintosh'un alması (Everdell, 2007, s. 18) gibi son derece akışkan tanımlar ortaya çıkmıştır. Bu akışkanlık postmoderniteye öyesine içkin haldedir ki postmodernitenin ve modernitenin en önemli soruşturmacılarından biri olan Zygmunt Bauman, postmodernite ile ilişkilendirilen dönemi "akışkan modernite" olarak isimlendirmiştir (Bauman, 2017, s. 12-13). Her şeyin akışkanlaştığı bu vasattan hakikat de payını almış ve "herkesin hakikati" ile birlikte "hakikatin müphemliği" anlayışı ortaya çıkmıştır. Dikkat çekici olan nokta, bu yılların, Chicago School of Economis ekolünün çerçevesini çizdiği şirket kapitalizminin yani neoliberalizmin (Emmett, 2009, s. 147) olgunlaştığı yıllar oluşudur. Neoliberal ekol 1980’li yıllardan itibaren Amerikan politikasında da karşılığını bulmuştur. Bunun başlıca nedeni bu yıllardan itibaren ülkenin artan askeri gücüne karşılık, Amerikan ekonomisinin tabanının II. Dünya Savaşı'ndan sonra ilk defa küçülmeye başlamış olmasıdır. O güne dek dünyanın en büyük kredi veren ülkesi olan ABD, 1980'lerin sonunda dünyanın en borçlu ülkesi haline dönüşmüş, kredi veren pozisyonunu Almanya ve Japonya'ya kaptırmıştır. ABD, benzer şekilde 1980'lerin başlangıcına kadar, kırk yıl boyunca, dünyanın en büyük ihracatçısı iken 1991'de kendisinin dörtte bir iş gücüne sahip olan Almanya'ya liderliği kaptırmıştır. 1980'de Citicorp ve Chase Manhattan dünyanın en büyük iki bankası iken 1991 yılında dünyanın en büyük on bankası Japon bankaları olmuştur. Amerika'nın en büyük bankası Citicorp dünya sıralamasında yirmi yedinci sıraya düşmüştür (Ambrose \& Brinkley, 2011, s. 379-380). Modernitenin temsilcisi konumundaki ABD’nin bu açmazdan çıkmak üzere ne tür askeri, siyasi ve entelektüel çabalar ürettiği tartışmaya açıktır. Belirgin olan şey bu aşamada, Soğuk savaş ortamındaki gerilimin yerel askeri çatışmalara dönüştüğü, Şili'deki ve Arjantin'deki yönetimlerin, ABD destekli olduğu iddia edilen askeri darbelere kurban gittiği, Vietnam Savaşı'nın ve Petrol Krizinin yaşandığı dünya siyaseti ve toplumları için son derece çalkantılı bir dönemin başladığıdır. Bu dönemin sonunda, dünyanın adeta neoliberal politikaları kucakladığı bir aşama başlamıştır. Türkiye'de de benzer şekilde, 12 Mart 1971 muhtırasının verilmesine ve yine ABD destekli olduğu iddia edilen 12 Eylül 1980'deki askeri darbeye kapı aralayan toplumsal 
hareketler bir vakum oluşturmuş ve darbenin hemen akabinde ithal ikameci politikaların terk edilip, neoliberal politikaların hayata geçirildiği (Erdem, 2019) bir atmosfer oluşmuştur. Ali Akay, Jürgen Habermas'ın Siyasi Yazılar'ında neoliberalizm ile postmodernizmi birlikte ele aldığını ve başlangıçta, neoliberal ekonomi ile postmodernizmin aynı döneme tekabül etmesinden dolayı, kavrama ağır eleştiriler yapıldığını, aktarır (Akay, 2013, s. 52). Benzer politik ve toplumsal örüntülerin dünyanın çeșitli coğrafyalarında hayata geçtiği, dünya siyaseti açısından son derece can alıcı olayların yaşandığı ve dünyanın kaynaklarının adeta yeniden bölüşüldüğü böylesine kritik bir dönemeçte kitlelerin gündeminin "hakikatin müphemliği" olması gerçekten de dikkat çekici bir gelişmedir. Hakikatin böylesine silikleştiği bir dünyada bir asırlık “büyük hakikatler”in yerlerinden edilerek, Jameson'ın “kapitalizmin yeni aşaması” olarak tariflediği aşamaya geçilmesi mümkün olmuştur. Neoliberal politikaların eşlik yeni toplumsallıklarla eş zamanlı olarak ortaya atılan postmodern felsefi açılamalar, dünyanın büyük bir köye dönüştüğünü, herkesin dünya vatandaşı olduğunu iddia eden küreselleşmeci siyasetin felsefi yakıtları arasında yerini almıştır. Bu yeni dünya sadece sermayenin küresel olarak rahatça dolaşabildiği ve başta gümrük vergileri olmak üzere önemli engellere takılmaksızın tüm dünyayı bir pazar olarak kurgulayabildiği bir dünya değil aynı zamanda, kendi “alternatif hakikatleri”ne tutunarak giderek atomize hale gelen bireylerin sübjektif dünyasıdır. Bu aşamadan, "hakikatin değersizliği”" aşamasına geçilmesi sadece bir zaman meselesi olmuş ve 2000'li yıllardan itibaren “hakikat sonrası çağ” tartışılmaya başlamıştır.

\section{Sonuç}

1980’lerde kullanılmaya başlayan ve 1990'ların ortalarında gündelik yaşamın bir parçası haline dönüşen internet teknolojisiyle birlikte hayatımıza giren "enformasyon/bilgi toplumu” kavramasallaştırmasının işaret ettiği gibi artık bilgi ve data okyanuslarında yüzüyoruz. Bilgiye ulaşmak bir yüzyıl öncesine göre dramatik bir şekilde kolaylaşmış ve demokratikleşmiş görünmektedir. Buna karşılık bilgi ile iç içe bir kavramsallaştırma olagelen "hakikat”"in bir kriz içinde olduğuna dair hissiyat, her geçen gün yaygınlaşmaktadır. İnsan yaşamını belirleyen bir ölçüt olarak binlerce yıldır kabul görmüş olan hakikat kavramına atfedilen bu kriz durumunun, enformasyon/bilgi çağı olarak adlandırılan bir dönemde ortaya çıkmış olması, içinde bulunduğumuz insanlık durumunun en büyük açmazlarından biri olarak görülmektedir.

1970'li yıllarda Amerikan üniversitelerinde tartışılmaya başlanan ve kısa süre içinde tüm dünyayı etkisi altına alan postmodernizm akımı ve onun önermesi olan "hakikatin müphemliği” yaklaşımı yerini, hakikatin reddedilmesi anlayışına bırakmaktadır. Bugün insanlığın hakikatle kurduğu çetrefilli ilişkinin entektüel tarafını postmodern felsefeciler, güncel tarafını da post-truth politikaların mimarları olan siyasetçiler, gazeteciler ve toplum liderleri temsil etmektedir. Ancak güncel konuşmalarımızın önemli bir kısmını işgal ettiği için nevzuhur bir problem olarak algılama eğilimi gösterdiğimiz bu tablo, kısa sayılamayacak bir sürecin son halkasıdır. Hikâyenin başlangıcı, Avrupa'nın çehresini değiştiren Aydınlanma hareketinin öncüllerine ve bu öncüller çerçevesinde hakikatin tanımlanış biçimine kadar uzanmaktadır.

17. yüzyıldan itibaren Avrupa vasatında ortaya çıkan Aydınlanma hareketi, hakikati, önceki hâkim paradigmadan bir hayli farklı şekilde tanımlamıştır. Buna göre; “hakikatin kaynağı ve ölçüsü” artık Tanrı değil insanoğlu olarak kabul edilmiştir. Başlangıçta “les philosophes” olarak anılan Aydınlanma'nın kurucu felsefecilerine hasredilmiş bu hak, zamanla sıradan insanların da talep ettiği bir hakka dönüşmüş ve bu durum postmodern teori ile kavramsal bir çerçeveye kavuşmuştur. Postmodern felsefeciler tarafından "postmodern durum” olarak isimlendirilen bu aşamadan sonra hakikat, her bireye özgü olarak biçim değiştiren, müphem ve sübjektif bir entiteye dönüşerek silikleşmeye başlamıştır. 2000'li yıllardan sonra ise nesnel ve elde edilebilir bir kategori olarak hakikatin artık aşıldığı ilan edilmiş ve "hakikat ötesi” tartışması bașlamıștır. Ancak 1970'li yıllardan itibaren yoğunluğu artarak devam eden hakikat tartışmasının, dünyanın siyasal ve ekonomik olarak içine sokulduğu atmosferden ve bütün insanlığı etkileyen gelişmelerden bağımsız olarak değerlendirilmemesi gerekmektedir. Hakikatin aşkın olanla bağlarının kesilmesinden sonra, ilk planda öznelleşmesi ardından da aşıldığının iddia edilmesi bu gelişmeler çerçevesinde anlamlı bir zemine oturmaktadır. İnsanlığın tartışmaya açık olmayan hakikatler üzerinde ittifak edemediği bu zemin, işgaller, soykırımlar, büyük çaplı göçler, kurumsallaşan sömürü ve gezegenimizin yaşanabilir bir yuva olmaktan çıkması ile sonuçlanan saldırılar karşısında ortak bir duruş geliştirmesinin önündeki en büyük engeldir.

\section{Son Notlar}

\footnotetext{
1 Enformasyon toplumu kavramsallaştırmasının ortaya çıkışı ve bu olgunun erken dönemli bir analizi için
}

${ }^{2}$ Bkz. Raymond Aron, Sosyolojik Düşüncenin Evreleri, Türkçesi: Korkmaz Alemdar, Ankara: Bilgi Yayınevi, 1994, Tom Bottomore, Robert Nisbet, Sosyolojik Çözümlemenin Tarihi, Ankara: Ayraç Yayınevi, 1997, Randall Collins, Sosyolojide Dört Ana Gelenek, Türkçesi: Ümit Tatlıcan, İstanbul: Sentez Yayıncılık, 2015, Bryan S. Turner, Klasik Sosyoloji, Türkçesi: İdil Çetin, İstanbul: i̇letişim Yayınları, 2014. 


\section{Kaynakça}

Akay, A. (2013). Postmodernizmin ABC'si. İstanbul: Say Yayınları.

Alatlı, A. (2011). Söyleși: Beyaz Türkler’i paçozluk küstürdü, Söyleşiyi Yapan: Şenay Yıldız, Akşam Gazetesi, 12 Eylül 2011, https://www.aksam.com.tr/roportaj/beyaz-turkleri-pacozluk-kusturdu--66691h/haber-66691.

Ambrose, S. E., \& Brinkley, D. (2011). Rise to globalism, American foreign policy since 1938. London: Penguin Books.

Bauman, Z. (2017). Akışkan modernite. (S. O. Çavuş, Çev.) İstanbul: Can Yayınları.

Castells, M. (2010). The rise of the network society (Information age; v. 1). UK: Wiley-Blackwell.

Çiğdem, A. (1993). Aydınlanma felsefesi. İstanbul: Ağaç Yayınları.

Duralı, Ş. T. (2000). Çağdaş küresel medeniyet, çağdaş küreselleştirilen İngiliz-Yahudi medeniyeti. İstanbul: Dergah Yayınları.

Eagleton, T. (1999). Postmodernizmin yansımaları. (M. Küçük, Çev.) İstanbul: Ayrıntı Yayınları.

Eisenstadt, S. N. (2007). Modernleşme, başkaldırı ve değişim. (U. Coşkun, Çev.) İstanbul: Doğu Batı Yayınları.

Emmett, R. B. (2009). Frank knight and the Chicago School in American economics. New York: Routledge.

Erdem, T. (2019). Türkiye'de darbe ve müdahalelerin kısa tarihi. https://www.sde.org.tr/tevfik-erdem/genel/ turkiyede-darbe-ve-mudahalelerin-kisa-tarihi-kose-yazisi-10443

Erdoğan, i. (2000). Kapitalizm, kalkınma, postmodernizm ve iletişim, sömürünün paketlenişi. Ankara: Kardelen Ofset.

Everdell, W. R. (2007). Ilk modernler, yirminci yüzyıl düşüncesinin kökenlerine ilişkin profiller. (H. Kocaoluk, Çev.) İstanbul: Yapı Kredi Yayınları.

Featherstone, M. (2013). Postmodernizm ve tüketim kültürü. (M. Küçük, Çev.) İstanbul: Ayrıntı Yayınları.

Gay, P. (1966). The enlightenments, an interpretation, the rise of modern paganism. New York: Alfred A. Knopf.

Giddens, A., \& Sutton, P. (2018). Sosyolojide temel kavramlar. (A. Esgin, Çev.) Ankara: Phoenix Yayınları.

Habermas, J. (tarih yok). modernity-an incomplete project.

Hof, U. I. (1995). Avrupa'da aydınlanma. (Ş. Sunar, Çev.) İstanbul: Afa Yayınları.

Jameson, F. (1991). Postmodernism, or the cultural logic of late capitalism. Durham: Duke University Press.

Küçük, M. (2018). Modernite versus postmodernite. Ankara: Say Yayınları.

Kumar, K. (2013). Sanayi sonrası toplumdan post-modern topluma çağdaş dünyanın yeni kuramları. (M. Küçük, Çev.) Ankara: Dost Kitabevi.

Lyotard, J. F. (2019). Postmodern durum. (i. Birkan, Çev.) Ankara: BilgeSu Yayınları.

Oxford Sözlüğü. (2021, 10 11). "Truth” maddesi. Oxford Sözlüğü: https://www.oxfordlearnersdictionaries. com/adresinden alındı

Robertson, R. (1993). Globalization, social theory and global culture. London: Sage Publications Ltd.

Sarup, M. (1995). Post-yapısalcılık ve post-modernizm, eleştirel bir giriş. (A. Güçlü, Çev.) Ankara: Ark Yayınevi.

Sarup, M. (2019). Post-yapısalcılık ve post-modernizm, eleştirel bir giriş. (A. Güçlü, Çev.) Ankara: Pharmakon Yayınevi.

Swingewood, A. (2014). Sosyolojik düşüncenin kısa tarihi. (O. Akınhay, Çev.) İstanbul: Mesele Kitapçısı.

TDK, (2021). “Hakikat” maddesi. Türk Dil Kurumu Sözlüğü: https://sozluk.gov.tr adresinden alındı

Wernick, A. (2003). Auguste Comte and the religion of humanity: The post-theistic program of French social theory. Cambridge: Cambridge University Press. 


\title{
MEDIAD \\ Medya ve Din Araștırmaları Dergisi | Journal of Media and Religion Studies
}

\section{Transformation of the Concept of "Truth": A Historical-Sociological Review}

\author{
Fatmanur ALTUN
}

\section{Extended Abstract}

"Truth" is among the most frequently used concepts in intellectual networks as well as everyday language. It originates from the fact that practically everyone, from ordinary people to society's leaders, is eager to explain themselves and their positions in respect to the truth in some way. This almost instinctual proclivity has resulted in truth being one of the most often cited concepts throughout history, and throughout history, there have been disagreements and consensus over the path to truth, the source of truth, and the arbitrariness of the authority possessing the truth. This human instinct to possess or at the very least take a side with the truth persists to the present day. Numerous explanations and discussions about the truth continue, with political and social implications. These discussions intensified particularly since the $1970 \mathrm{~s}$ and continue to the present day, accompanied with calls for "end of truth".

Mankind's relationship with truth is a cosmic criterion that defines their journey on Earth. For humans sometimes demand and sometimes reject the truth. This situation confronts humanity with highly complex problems in today's world, where information is increasing exponentially in comparison to the past, we are rapidly transforming into "information/information societies," and we are swimming in oceans of knowledge, and a social tendency known as denial of truth emerges. The postmodernism movement, which began to be discussed in American universities in the 1970 s and affected the entire world in a short time, especially with the effect of the post-structuralism wave that came to the agenda in Continental Europe in the 1960s, and its subsequent proposition the "ambiguity of truth" approach, is the most recent representation of this viewpoint, which has been encountered from time to time in human history. Postmodern philosophers are thought to represent the intellectual side of humanity's complex relationship with truth today.

Indeed, the emergence of the concept of postmodernity as a tool for social criticism and analysis has a socio-political and socio-cultural context. Postmodernity has emerged as a natural result of Western modernity, the foundations of which were laid in the 17th century with the Enlightenment. Following the era of great reforms that began after 1789 and the events that occurred during this era, the power of the Church and aristocracy in Europe faded, the bourgeoisie became the dominant class of the European social structure, and the modern Western civilization as we know it today emerged, complete with all of its institutions and social mechanisms. This civilization, which was the source of the mentioned Enlightenment, was the first and only civilization that did not define its source as supernatural and emerged in history since the end of the 16 th century. Western civilization, which rejects and cuts off all supernatural sources such as revelation, has also considered reason and conscience, which are essentially religious terms, as independent elements. The self-reliant mind vision of the Enlightenment mentality refused to accept transcendent power as the source of truth. After this stage, it was accepted that "the source and measure of truth are not God, but human beings," and the dramatic effects of this acceptance on human life emerged.

Even though the Enlightenment mind viewed humans as "the source and measure of truth," it did not foresee ordinary people exercising this right. The state of being the source and measure of truth, which was initially thought to be peculiar to philosophers, known as "les philosophes," began to attract ordinary people over time. The truth has taken its share from the democratic demands that have grown with the spread of modernity, and ordinary people have begun to serve as the source and measure of truth. This shift in truth has finally revealed the historical period known as the "postmodern situation." 
Postmodernism proposed the theory of a world in which "everyone's truth belongs to oneself." As a result, humanity has faced the problem of "ambiguity of truth" since the 1970s. The remarkable thing about these years is that they marked the maturation of corporate capitalism or neoliberalism. Since the 1980 , the neoliberal school has found its way into American politics. The main reason for this is that the American economy's base has shrunk for the first time since World War II, despite the country's increasing military power during these years. The United States, which had previously been the world's largest creditor country, became the world's most indebted country at the end of the 1980s, losing its creditor position to Germany and Japan. Similarly, while the United States was the world's largest exporter for forty years until the early 1980s, it lost the lead in 1991 to Germany, which had a quarter of its workforce. While Citicorp and Chase Manhattan were the world's two largest banks in 1980, the ten largest banks in 1991 were Japanese banks. Citicorp, America's largest bank, had dropped to twenty-seventh in the world rankings. It is debatable what kind of military, political, and intellectual efforts the United States, as the representative of modernity, made to break free from this impasse. The obvious thing at this point is that the Cold War tensions have turned into local military conflicts, the governments of Chile and Argentina have fallen victim to alleged US-backed military coups, the Vietnam War and the Oil Crisis have emerged, and a very turbulent period for global politics and societies has begun. At the end of this period, a phase in which the world almost embraced neoliberal policies began. It is indeed an intriguing development that the "ambiguity of truth" was on the agenda of the masses at such a critical juncture, when similar political and social patterns were adopted in various geographies of the world, extremely vital events were experienced in terms of world politics, and the resources of the world were almost redistributed. In a world where truth has become so obscure, displacing a century of "great truths" has enabled the transition to the stage Jameson called the "new stage of capitalism" to emerge. Postmodern philosophical explanations proposed at the same time as neoliberal policies philosophically fuelled globalist politics, which argued that the globe had become a vast village in which everyone was a global citizen. This new world includes not only a world where capital may easily circulate globally and develop the entire world as a market without major restrictions, particularly customs charges, but also the subjective world of individuals who have become increasingly atomized by adhering to their own "alternative truths,". The transition from this stage to the "insignificance of truth" stage was only a matter of time, and the "post-truth era" began to be discussed in the 2000 s.

Today, we frequently hear that reaching the truth is unattainable, that the truth has lost its significance as a value, and that we have entered a world post-truth. The origin of these ideas, in particular, cannot be grappled with independently of the truth's transformation, which started to take shape with the Enlightenment and began to penetrate ordinary people's agendas through arguments surrounding post-truth, etc. This study was prepared to analyze the historical context of the "truth" problem, which has begun to be recognized as a present and universal issue, especially with the advancement of internet technology and the widespread use of social media tools. In this framework, it's claimed that the Enlightenment's understanding of "human as source and measure of truth" has evolved to an unanticipated stage with postmodernity; as a natural result of this understanding, the doors to a world where everyone can have their own truth were opened, and the discourse of "alternative truths" has opened up the concept and phenomenon of truth itself for discussion. 
Araștırmacıların Katkı Oranı Beyanı/ Contribution of Authors

Araştırma tek bir yazar tarafından yürütülmüştür.

The research was conducted by a single author.

$* * * * * * * *$

\section{Çıkar Çatışması Beyanı / Conflict of Interest}

Çalışma kapsamında herhangi bir kurum veya kişi ile çıkar çatışması bulunmamaktadır.

There is no conflict of interest with any institution or person within the scope of the study.

$* * * * * * * *$

\section{Intihal Politikası Beyanı / Plagiarism Policy}

Bu makale iThenticate yazılımıyla taranmıştır. Intihal tespit edilmemiştir.

This article has been scanned by iThenticate. No plagiarism was detected.

$* * * * * * * *$

\section{Bilimsel Araștırma ve Yayın Etiği Beyanı / Scientific Research and Publication Ethics Statement}

Bu çalışmada “Yükseköğretim Kurumları Bilimsel Araştırma ve Yayın Etiği Yönergesi” kapsamında uyulması belirtilen kurallara uyulmuştur.

In this study, the rules stated in the "Higher Education Institutions Scientific Research and Publication Ethics Directive" were followed 